\title{
Refugee Camps and the Spatialization of Assyrian Nationalism in Iraq
}

\author{
L. Robson
}

\section{Introduction}

During the interwar period, Iraq became home to a number of Assyrian communities who had been displaced by Ottoman massacres and the exigencies of World War I. The refugee camps created to house them soon became spaces where international organizations operated as state-like actors, determining the layout of the physical space, running local bureaucracies, and distributing goods and services. At the same time, the experiences of these refugee communities provided a foundation for diaspora groups to create nationalist and separatist political narratives for international distribution. The transnational nature of Assyrian and Armenian refugee communities, combined with the semi-permanent nature of their camp dwellings and their dependence on external entities for their maintenance, lent these spaces a sense of separation from the emerging urban and rural landscapes of the new Iraqi state. This essay examines how such camps contributed to minoritizing not only communities but spaces, and helped to further strands of Iraqi and Arab nationalism that were coming to view minorities as an entry point for western intervention.

The particulars of the refugee regime, as embodied especially clearly in the example of the Ba'quba refugee camp in Iraq, set the stage for a permanent role for refugee camps in the mandate states of the interwar Middle East. They were conceived not just as institutions for immediate humanitarian relief but as places for the preservation and continuance of Armenian and Assyrian "national" identities while the refugees waited for the emergence of a sovereign state. In the absence of any practical movement towards sovereign nationhood for Iraq, Syria, Lebanon, or Palestine, the British government and the League of Nations presented such refugee camps as visible evidence of the League's and the mandate powers' theoretical commitment to principles of national sovereignty. 


\section{Nationalism and Humanitarianism}

The refugee regime in postwar Iraq emerged out of two longer-term trends: western mission interest in Assyrian communities that dated to the nineteenth century, and its extension in the form of massive aid campaigns in Britain, France, and the United States, spearheaded by missionary and church groups during the course of World War I. The construction of Assyrian identity as specifically national, rather than religious, communal, or ethnic, owed much to the machinations of western missionary intervention and interest in the region prior to the war. Its furthering in the context of the postwar refugee crisis in part reflected the mission origins of refugee aid and the nature of the international campaign to raise money and awareness for the plight of displaced ex-Ottoman Christians.

In the eighteenth and nineteenth centuries, the European powers-particularly Britain, France, and Russia-began to develop the idea of serving as "protectors" of the Christian subjects of the Ottoman Empire, as a mode of intervening in the failing Ottoman state as well as appealing to a growing evangelical interest in eastern Christians in their respective domestic spheres. Many of these relationships were formalized in the set of treaties, collectively known as the "Capitulations," established between the weakened Ottoman state and the rising European empires. ${ }^{1}$ In a number of cases, external European interest in the political benefits of alliances with these communities overlapped with an increased missionary presence interested in establishing a western Christian presence in what was increasingly called and understood as the "Holy Land." The nineteenth-century rise in biblical archaeology and mass evangelical tourism, particularly in Britain and the United States, led mission orga-

1 For detailed discussions of this system of "protections," see Benjamin Braude and Bernard Lewis (eds.), Christians and Jews in the Ottoman Empire: The Functioning of a Plural Society, 2 vols. (New York: Holmes and Meier, 1982); Bruce Masters, Christians and Jews in the Ottoman Arab World: The Roots of Sectarianism (Cambridge: Cambridge University Press, 2001); Youssef Courbage and Phillipe Fargues, Chrétiens et juifs dans l'Islam arabe et turc (Paris: Fayard, 1992); and Xavier de Planhol, Minorités en Islam: géographie politique et sociale (Paris: Flammarion, 1997), as well as descriptions in broader histories of the empire like Donald Quataert, The Ottoman Empire, 1700-1922 (New York: Cambridge University Press, 2000); Halil Inalcik et al. (eds.), An Economic and Social History of the Ottoman Empire, 1300-1914, 2 vols (Cambridge: Cambridge University Press, 2004); Fadil Bayat, al-Dawla al-Uthmaniyya fi l-majal al-Arabi: dirasa tārīkhiyya fí l-aw da' al-idariyya fì daw' al-wathä’iq wa-l-masādīr al-Uthmaniyya ḥașran (Beirut: Markaz Dirasat al-Wahda al-'Arabiyya, 2007); and Caroline Finkel, Osman's Dream: The Story of the Ottoman Empire 1300-1923 (New York: Perseus, 2005). 
nizations to begin to establish outposts across the Ottoman sphere, particularly in the Levant. Since proselytizing to Muslims constituted a crime in the Ottoman Empire, and the small Jewish communities who were sometimes a target of mission efforts remained largely unresponsive, missionaries often turned their attention to local Christian communities, who they believed would benefit from western-style education and exposure to the practices of western Christianity. ${ }^{2}$ This three-way association between local Christian communities, western missions, and the machinery of European diplomacy went a long way in shaping the fate of these communities through the twentieth century.

The small Assyrian Christian communities of the nineteenth-century Hakkari region (encompassing parts of modern-day northern Iraq, northwestern Iran, and eastern Turkey) became targets of this western Christian attention in an especially intensive way. Like other indigenous Christian communities in the Middle East, throughout the nineteenth century the Assyrians had been objects of interest for British and American Protestant missions; unlike most of these other Christian communities, the Assyrians also interested archaeologists. The rising European missionary presence in the Hakkari region coincided with a number of archeological excavations of the ancient ruins of Nineveh and Babylon, and especially with the discovery of the Nimrud palace of Ashurnasirpal II in 1848. Missionaries drew on these recent discoveries of pre-Islamic Assyrian greatness to promote the idea of this branch of eastern Christians as direct descendants of this ancient empire. "The present Assyrian," one missionary wrote in 1929, "does represent the ancient Assyrian stock, the subject of Sargon and Sennacherib ... The writer has known men who claimed to be able to trace their own lineal descent from King Nebuchadnezzar." ${ }^{3}$ As historical sociologist Sami Zubaida notes, this "constructed Assyrian identity could then

2 On this history of western Christian missionary activity in the Middle East, see especially Eleanor H. Tejirian and Reeva Spector Simon, Conflict, Conquest, and Conversion: Two Thousand Years of Christian Missions in the Middle East (New York: Columbia University Press, 2012); Heleen Murre-van den Berg (ed.), New Faith in Ancient Lands: Western Missions in the Middle East in the Nineteenth and Early Twentieth Centuries (Leiden: Brill, 2006); Mehmet Ali Dogan and Heather J. Sharkey (eds.), American Missionaries and the Middle East:Foundational Encounters (Salt Lake City: University of Utah Press, 2011); and Ussama Makdisi, Artillery of Heaven: American Missionaries and the Failed Conversion of the Middle East (Ithaca: Cornell University Press, 2008).

3 W. Wigram, The Assyrians and their Neighbors (London: Bell Press, 1929): 178-179; also cited in Madawi al-Rasheed, Iraqi Assyrian Christians in London: The Construction of Ethnicity (Lewiston, NY: Edwin Mellen Press, 1998), 42. 
draw on two sources of favourable associations: ancient national ancestry and a Christianity which forged linked with the dominant European powers." ${ }^{4}$ It was during the late nineteenth century that western missionaries began to popularize the word "Assyrian," previously only one of a number of possible designations for these Christians and not the most prominent, as a mode of identifying the present-day community with the ancient empires. Originally, this idea may have been suggested by local assistants to the excavations like the Assyrian activist Hormuzd Rassam; certainly it buttressed community ambitions for local autonomy, as well as romantic missionary imaginings of an untouched "original" Christian community. ${ }^{5}$

Consequently, even before World War I, the beginnings of a re-categorization of Assyrian identity from communal and ethnic to national were already underway. The centralization of Ottoman authority in the final years of the empire, as the Ottoman state tried to take firmer hold of its borderlands, also assisted this process, as Assyrian leaders sought to defend their longstanding autonomy in Hakkari and resisted closer surveillance and incorporation into the Ottoman sphere. ${ }^{6}$ In this fight, many Assyrian leaders saw their association with western missionaries and archeologists as potentially beneficial to their cause, and began to adopt a mission-derived language of national independence for their own purposes. ${ }^{7}$ The missionary presence also created new venues for the dis-

4 Sami Zubaida, "Contested Nations: Iraq and the Assyrians," Nations and Nationalism 6, no. 3 (2000): 373 .

5 J. Coakley, The Church of the East and the Church of England (Oxford: Clarendon Press, 1992), 5. Until the early twentieth century, the Assyrians generally referred to themselves as nestoryaye, the Nestorian millet, an Ottoman designation that had no national or ethnic overtones. Protestant missionaries were especially anxious to erase the designation "Nestorian" from the community they had decided to champion, as it referred to a "heretical" theology. For the dual Assyrian/missionary making of this new version of Assyrian nationalism, see particularly Heleen Murre-van den Berg, "Chaldeans and Assyrians: The Church of the East in the Ottoman Period," in Erica Hunter (ed.), The Christian Heritage of Iraq (Piscataway, NJ: Gorgias Press, 2009), 157-161.

6 On this point, see especially Michel Chevalier, Les montangnards chretiens du Hakkari et du Kurdistan septentrional (Paris: Departement de Geographie de l'Universite de Paris-Sorbonne), and Heleen Murre-van den Berg, "Light from the East (1948-1954) and the DeTerritorialization of the Assyrian Church in the East," in Wim Hofstee and Arie van der Kooij (eds.), Religion Beyond its Private Role in Modern Society (Leiden: Brill, 2013), 115-134.

7 For detailed accounts of the Assyrian encounter with western missions, see particularly John Joseph, The Modern Assyrians of the Middle East: Encounters with Western Christian Missions, Archeologists, and Colonial Powers (Leiden: Brill, 200o), and Coakley, The Church of the East and the Church of England. 
semination of this new national identity, as mission schools became important educational institutions for Assyrians and the printing press allowed for the publication and distribution of both religious and secular material in modern Aramaic. $^{8}$

As the war approached and the Ottoman government broadly began to view its Christian subjects as potential threats to the state, the Assyrian relationship with the beleaguered Ottoman administration began to erupt into violence. ${ }^{9}$ The increasingly hostile encounters between Assyrian Christians and a Muslim Turkish dominated Ottoman government gave Assyrian supporters in the West further reason to describe the community as a religiously persecuted "nation." In 1915 and 1916, when Armenians and Assyrians were being massacred in the eastern reaches of the Ottoman Empire, western groups like the American organization Near East Relief called for donations not only to relieve the suffering of those Armenian and Assyrian populations dispossessed and persecuted in the war, but also to save their existence as civilized Christian "nations" facing the wrath of a benighted, barbaric Muslim rage. ${ }^{10}$ This kind of rhetoric predicated international aid on the premise that donors were not only rescuing individual victims but also preventing the disappearance of national bodies, thus casting the idea of a postwar assimilation into the new states of Syria and Iraq as a kind of national and even racial annihilation. This rhetoric of aid, and its dissemination through church and diaspora networks, helped to legitimize and reinforce the creation of the Assyrian refugee camp as a space for the expression of a specific form of national statelessness.

This narrative of Assyrian Christian nationhood and civilization versus Turkish Muslim barbarism represented an especially prominent trope in the reams

$8 \quad$ Murre-van den Berg, "Chaldeans and Assyrians," 158.

9 A number of recent scholarly works advocate labeling this violence an "Assyrian genocide" to be acknowledged alongside the Armenian genocide. On this point and on the numbers of Assyrians deported and massacred, see especially David Gaunt, Massacres, Resistance, Protection: Muslim-Christian Relations in Eastern Anatolia During World War I (London: Gorgias Press, 2006); Hannibal Travis, Genocide in the Middle East: The Ottoman Empire, Iraq, and Sudan (Durham, NC: Carolina Academic Press, 2010), and idem, "The Assyrian Genocide: A Tale of Oblivion and Denial," in Rene Lemarchand (ed.), Forgotten Genocides: Oblivion, Denial, and Memory (Philadelphia: University of Pennsylvania Press, 2011); Cathie Carmichael, Genocide Before the Holocaust (New Haven: Yale University Press, 2009); and Sébastien de Courtois, Le génocide oublié: chrétiens d'orient, les derniers araméens (Paris: Ellipses, 2002).

10 On this point see especially Keith Watenpaugh, "The League of Nations' Rescue of Armenian Genocide Survivors and the Making of Modern Humanitarianism, 1920-1927," American Historical Review 115, no. 5 (2010): 1315-1339. 
of petitions sent from Assyrian diaspora communities to the British government and the various representatives at the Paris peace conference. The Assyrian National Associations of America, based in New York and with branches throughout New England, advocated for an independent Assyrian state to be carved out of Kurdistan and Mesopotamia on precisely these grounds:

... the centuries have proved that the Turks are incapable of reform, and the Arabs are not accustomed to any form of government. The history of Turkish Government and its cruel deeds are known to the world; fertile lands lie sterile under the dead hand of the Turk, whereas Assyrians in their country are successful in every branch; they are an intelligent, industrious and prolific race. Assyrians have lived under centuries of cruelty and persecution. Their faithfulness to their nationality and religion have saved them from extermination. ${ }^{11}$

This focus on racial extermination provided a useful counterpoint to the idea of Assyrian absorption into a multi-ethnic and multi-religious state such as those being proposed in Palestine and Iraq. Many of these petitions laid out lengthy descriptions of an ancient Assyrian Christian nation in danger of total eradication without western intervention and recreation as a sovereign or semi-sovereign space.

For Assyrian diaspora communities in the West, this rhetoric of ancient Christian nationhood was especially powerful because it represented a crucial mode of assimilation. By accepting and promoting ideas of Turkish Muslim barbarism set beside Assyrian and Armenian national and religious commitment, they could claim a space in "Western civilization" that would make absorption into the United States, France, England, and Australia (among others) an easier task. In some cases, particularly in the United States, this claim to Christian nationhood could make it possible to claim the legal category of "white" and its corresponding legal and political privileges. ${ }^{2}$ These diaspora conversations, which promoted a vision of minority nationalisms invented in the context of late nineteenth-century missionary activity, lent legitimacy to the maintenance of Assyrian refugee camps as separate national spaces in the postwar context.

11 Executive Committee, Assyrian National Associations of America, memo on "The New Assyria," 29 March 1919, National Archives Kew Foreign Office (henceforth Fo) 608/274.

12 See Sarah Gualtieri, Between Arab and White: Race and Ethnicity in the Early Syrian American Diaspora (Berkeley: University of California Press, 2009). 


\section{Ba'quba}

The first Armenian/Assyrian refugee camp in Iraq, set up in the northern village of Ba'quba, became a space within which these longstanding tropes were explicitly rendered into a new physical and spatial reality. Set up to house Armenian and Assyrian communities who had found themselves engaged in a military campaign against Russia in the final stages of the war, it became a physical manifestation of British ethnographic categorizations and of British and League commitment to the principles of national sovereignty, and served as one of the initial examples of how refugee camps could themselves begin to operate as political spaces independent of the states in which they were located.

At Urmia in the spring of 1918, a group of Assyrians originally from the Hakkari region, along with a small and mostly local Armenian force, were engaging in battle against the Ottomans (and, sporadically, against local Kurdish tribes as well). That June, a British force sent from Hamadan landed in Urmia and informed the holdouts of the British military advance to Sarin Qalaa. The remaining Assyrians and Armenians evacuated Urmia under British protection and left for Hamadan, where the British formally incorporated the Armenian soldiers into the British army and charged them with the task of moving and protecting the refugees. Anticipating the declaration of British control over what would become Iraq, British officials marched the Assyrian and Armenian communities several hundred miles to the village of Bacquba, just north of Baghdad, where a camp was under construction to serve as a temporary solution to the refugees' homelessness.

At this juncture the British hold on Mesopotamia, and the nature of its future governance, was still very uncertain. There was considerable resistance to the imposition of British rule across Iraq, and already several anti-colonial societies encompassing both Sunnī and Shīī leaders had sprung up in the cities to organize the anti-British campaign. Though founders of the nascent League of Nations were in discussions with the British over the precise nature of its rule over Iraq and the nature of the proposed "mandate" system, it had no formal mechanisms yet in place to provide oversight or suggest policy. Indeed, these mechanisms remained weak throughout the mandate period; as Peter Sluglett has recently put it, "The framers of the mandate system thought they were improving on colonialism, but given the fact that they all had 'conventional' colonial empires of their own, and given the poverty of the regulatory machinery, the outcome was not all that different from the colonized countries." ${ }^{.13}$ At 
any rate, the nature of mandate rule in Iraq did not really solidify for another several years, until after a widespread revolt in 1920 forced the reformulation of the mandate for Mesopotamia into the Kingdom of Iraq via the 1922 AngloIraqi Treaty and initiated a partial devolution of power into Iraqi hands. ${ }^{14}$ The creation of the Baquba camp was therefore very much under local control and dictated initially by the British officials on the ground, in cooperation with a refugee Assyrian military leadership with whom the British had established a relationship.

The inhabitants of Ba'quba now included 24,579 Assyrian refugees, nearly all originally from Hakkari, along with 14,612 Armenians from Van, Mosul, and Urmia. The British officials in charge made decisions about the camp's administration without much contact or input from London and none at all from Geneva. They viewed the camp as having three central purposes: first, to house refugee populations on a temporary basis with a view towards repatriation; second, to promote, record, and "preserve" what they understood as the national

Middle East,"International Affairs 90, no. 2, (2014), 425. The question of the degree to which the mandate system represented a genuinely new form of government versus a repackaged European imperialism has received extensive notice. In general, scholars of the Middle East have viewed it as little more than a fig leaf for the continuation of earlier forms of British and French imperial rule; for some examples, see particularly Nadine Méouchy and Peter Sluglett (eds.), The British and French Mandates in Comparative Perspective (Leiden: Brill, 2004); Philip Khoury, Syria and the French Mandate: The Politics of Arab Nationalism, 1920-1945 (Princeton, NJ: Princeton University Press, 1987); Daniel Neep, Occupying Syria under the French Mandate: Insurgency, Space, and State Formation (Cambridge: Cambridge University Press, 2012); Elizabeth Thompson, Colonial Citizens: Republican Rights, Paternal Privilege, and Gender in French Syria and Lebanon; Laura Robson, Colonialism and Christianity in Mandate Palestine (Austin: University of Texas Press, 2011); Jacob Norris, Land of Progress: Palestine in the Age of Colonial Development, 1905-1948 (Oxford: Oxford University Press, 2013); and Daniel Silverfarb, Britain's Informal Empire in the Middle East: A Case Study of Iraq, 1929-1941 (New York: Oxford University Press, 1986). Historians viewing the League from a European perspective have sometimes had a slightly different view of the nature of the mandate system; see, for example, Susan Pedersen, "The Meaning of the Mandates System: An Argument," Geschichte und Gesellschaft 32, no. 4 (2006), 560-582, which assigns a bit more importance to the distinction between colonial and mandate governments.

14 On the creation of the modern state of Iraq, the widespread revolt of 1920, and the reformulation of the mandate into the Hashemite monarchy, see particularly Reeva Simon and Eleanor Tejirian, The Creation of Iraq, 1914-1921 (New York: Columbia University Press, 2004); Charles Tripp, A History of Iraq (Cambridge: Cambridge University Press, 200o); and Toby Dodge, Inventing Iraq: The Failure of Nation Building and a History Denied (New York: Columbia University Press, 2003). 
cultures of the Armenians and Assyrians; and third, to create an orderly "modern" space distinct from the geographical location and therefore essentially mobile. All three of these premises became models for understanding refugees and the place of camps in the new international order. Although Ba'quba did not last long, it provided a model on which the British and the League based their understanding of the postwar refugee problem and the range of possible solutions into the interwar period, as the conceptual framework for an international refugee regime was solidified, standardized, and incorporated into international legal and political structures.

The basic premise of the camp at Ba'quba was that it represented a temporary solution and that the refugees were preparing for repatriation and resettlement. The refugees themselves were passionately in favor of an eventual repatriation to Hakkari and Urmia, as was demonstrated by any number of lobbying efforts and a failed attempt by the Assyrian leader Agha Petros to take a group back into Hakkari in 1920. Dr. J.M. Yonan and Pepa Mirza, both members of the Assyrian National Committee based in Urmia during the war, appealed to the British Legation in Tehran for assistance in resettling the Assyrians back into Urmia on the basis of their military assistance to the British and the refusal of the Persian government to offer assistance. "These are the conditions and these are the sacrifices," they wrote,

and we therefore pray the Allies and most especially Great Britain 1. To return our people to Urumia [sic] 2. To grant our people protection without which is would be impossible to reside in Urumia. We would especially beg that protection be granted and guaranteed to the members of the Central National Committee who had been very active in the arrangements of National affairs and therefore have incurred the special enemity [sic] of Turks and Kurds and Persians who are pro Turkish. ${ }^{15}$

Another Assyrian statement of political goals, sent from a committee to the British headquarters in Baghdad with a view towards having it read at the peace talks, requested "re-establishment in own country under British protection," clarifying that this meant the region of "Kurdistan up to line of Jezireh-SeriBash-Kala and Persian territory between Lake Urmi and Turkish frontier," and "Government recognition of Patriarch Marshimmun as head of nation," accom-

15 J.M. Yonan and Pera Mirza, memo on "The Assyrian People and their Relations with the Allies in the Present War," Dec. 1918, Fo 608/274. 
panied by an assurance that "if granted these things hope to live peaceably with Kurds under British protection."16

Such demands did not indicate a national determination to acquire Assyrian nation-state sovereignty but rather a desire to return to the relatively autonomous political position the Assyrians had enjoyed in the late Ottoman period, in the same geographical space. Even the redoubtable Surma Khamman, sister of the late patriarch and enthusiastic advocate for Assyrian affairs in London, despite her practiced promotion of Assyrian national identity to sympathetic British officialdom, proposed that membership in an independent Kurdistan might represent a viable future for the Assyrians: "Should prefer British protection and mandate for Hakkiari district, but recognize this impossible. If Kurdistan independent could live there in Hakkiari in old homes with Kurds, supposing armament provided for self-protection. Much prefer this alternative [to repatriation to Persia or Turkish territory]."17

British advocates for Assyrian nationhood, though, constructed this enthusiasm for return as an expression of national commitment, and began to prepare for mass refugee resettlement as part of a creation of autonomous Assyrian and Armenian nation-states - this despite the fact that already the idea of autonomous Assyrian and Armenian states had clearly been rejected as a governing principle of a postwar order. As a London official minuted in 1919, "The new Mesopotamia will give the Assyrians their real desiderata (i) security and (ii) union in a single state (though this state will of course not be a national Assyrian state, but Arab-Kurdish-Syriac). ${ }^{\prime 18}$ Nevertheless, the fiction of a future sovereign nation-state governed refugee camp administration and planning. It also began to produce the narrative that statelessness was not merely a condition of lack of citizenship, but rather a condition of citizenship in a state that did not actually exist as a political entity. Refugee statelessness, therefore, emerged as a concept that applied to Assyrians and Armenians but not to Turkish or Kurdish displaced populations, and camps like Baquba were presented as a solution specifically designated for "national" populations in a condition of temporary limbo while their states were being created. Consequently, while the British and French taking over their new mandated territories in Iraq and Syria pursued tactics of sedentarization and local resettlement for displaced Kurdish, Yedizi, and Arab populations in the borderlands, ${ }^{19}$ they grouped Armenians and Assyrians in "refugee camps" (itself a relatively new concept) that

\footnotetext{
16 Memo from Political Bureau Baghdad to London, 11 March 1919, Fo 608/274.

17 Surma Khassan to Matran, 5 May 1920, T 1/12603.

18 Minute on Political Bureau Baghdad memo, 11 March 1919, Fo 608/274.

19 On this, see especially Seda Altug, "Sectarianism in the Syrian Jazira: Community, Land
} 
had the specific and explicitly stated purpose of acting as a waystation on the path to sovereign statehood and expressed a nationalized political landscape.

This aspect of the camp did not emerge immediately, as there were many casualties of the long trek from Hamadan to Ba'quba and many who did survive the journey were in poor health upon their arrival. Initially, conditions at the camp were chaotic and unsanitary; one British army officer working there reported a stream of destitute arrivals and more than eighty deaths daily in the early days of the camp. But as time went on and it became clear that the camp was at least a semi-permanent institution, in the absence of any viable possibility of immediate repatriation, the British officers in charge of the camp began to organize its population to reflect and prepare for a future in which both Armenians and Assyrians would have their own nation-states.

A memorandum on the camp reported an initial process of separating refugees by ethnicity into defined national spaces: "For the first month or so the people were all mixed up, Armenians and Assyrians together. But as they became more settled, a census was held, and the people arranged throughout the sections according to their tribal divisions and affiliations." 20 The British camp administrators also set up committees to deal with "questions of national customs and religious duties,"21 which they considered central to the preservation of Armenian and Assyrian national character until the communities could be reconstituted in a "homeland." To that end, daily life in the camp included instruction in Armenian and Syriac for the children, classes in traditional Armenian lace-making and sewing for the women, and the careful recording of Armenian and Assyrian customs.

The conception of the camp as a space for the preservation of the "race" became central to the stated principles of the British officers in charge. H.H. Austin, the camp commandant, recorded that this idea had to be conveyed and enforced to the refugees themselves:

The proportion of deaths among newly-born infants at one time became so high, particularly with the Assyrians, that I pointed out to Mar Shimun there seemed, in the opinion of my medical officers, to be good reason for believing that mothers were in the habit of purposely overlying their

and Violence in the Memories of World War I and the French Mandate (1915-1939)" (PhD thesis, Utrecht University 2011), and Nelida Fuccaro, The Other Kurds: Yazidis in Colonial Iraq (London: Tauris, 1999).

20 Memoranda, 6; also quoted in Jo Laycock, Imagining Armenia: Orientalism, Ambiguity, and Intervention (Manchester: Manchester University Press, 2009), 168.

21 Laycock, Imagining Armenia, 168. 
babies shortly after birth ... I begged him to appeal to mothers to do everything in their power and to take full advantage of the facilities afforded by our maternity wards, to rear up their infants. The nation was already so reduced in numbers by their sufferings during the war that it was simply race suicide if this high death rate amongst babies was allowed to continue. In response to my request the Patriarch issued a proclamation to all mothers, and expectant ones, exhorting them for the sake of the future welfare of the nation to give every care to newly-born children. ${ }^{22}$ [Emphasis added]

Such language indicated the degree to which British and American administrators were engaged in constructing particular kinds of narratives about the camps as national spaces and about the refugees as survivors of an attempted holocaust, and needed the assistance of Assyrian and Armenian collaborators to broadcast these messages to the refugees themselves. As Dudley Northcote, one of the British officials in charge of the Armenian sections of the camp, noted in a letter home,

If you are an ordinary regimental officer in a British regiment, it is astonishing how little opportunity you have of getting to know anything about the natives of Messpot [sic], because of course all your work is with your own men, but now it is part of my job to study 1300 Armenian men, women and children. ${ }^{23}$ [Emphasis added.]

He added in a different context how utterly dependent he was on his "headman," who had spent some of his early years in the United States and could speak English "after a fashion." 24

Under British authority, the camp became a disciplined and self-contained space in which access to Arab and Kurdish Iraq was restricted and government and social organization was entirely internal. The military officers in charge of its administration imagined it as a carefully organized, mapped-out institution:

The whole camp which covers roughly an area of one square mile has been divided into three areas: 'A,' 'B,' and 'C' respectively. Each of these areas are subdivided into sections, varying from 11 to 13 in number in each

\footnotetext{
22 H.H. Austin, The Ba'qubah Refugee Camp: An Account of Work on Behalf of the Persecuted Assyrian Christians (London: Faith House, 1920), 42.

23 Letter to "Mamma," 3 Dec. 1918, Northcote papers (henceforth NP), British Library.

24 Northcote to "Papa," 11 Dec. 1918, NP.
} 
area. Over each area there was a British officer, and each section had a British officer looking after it assisted by 3 or 4 British soldiers. ${ }^{25}$

Another observer praised the way the "tribal census" had made a mapping out of the ethnic territory of the camp:

As a result of the "General Post," the Armenians were all located in ' $\mathrm{A}$ ' area; whilst ' $\mathrm{B}$ ', and ' $\mathrm{C}$ ' were occupied by Assyrians, who were arranged throughout the sections in accordance with their tribal divisions and affiliations. The supply, and other questions of administration and discipline were greatly simplified in consequence. ${ }^{26}$

The Assyrian and Armenian children in the orphanage section of the camp were kept mainly separate: "The large cook-house and bathing-sheds were common to both Armenian and Assyrian children; but they worked at lessons and played apart-each nationality having its own school tents, and giantstrides, horizontal and parallel bars, swings, see-saws, etc."27

Camp schools also revolved around this idea of maintaining collective racial and ethnic memory. Levon Shahoian, who was eleven years old at the time of his sojourn in Ba'quba, recalled the schooling as little more than a process of recollection: "For days at end our sole curriculum was repeating out own names and family names. We had to stand up and repeat our, as well as our father's and mother's name, the names of our siblings, and the city or village from where we had been exiled." ${ }^{28}$ Armenian nationalist history and language, along with English lessons taught by a group of American missionaries, constituted the remainder of the curriculum.

Employment was entirely controlled by the British military, which put the men in the camps to work distributing supplies and building roads, drains, and other infrastructure. Some of these jobs were outside the camp, but they were assigned and paid through the British army and did not involve significant contact with the Kurdish and Arab populations in the surrounding area. Such contact as did occur was often hostile, with sentries firing on Arabs approaching the camp in an attempt to "prevent Arab thieves getting into one part or another of the camp at night, and stealing animals and private property of

\footnotetext{
25 Memoranda, cited in Laycock, Imagining Armenia, 158.

26 Austin, The Ba'qubah Refugee Camp, 20.

27 Ibid., 24.

28 Levon Shahoian, On the Banks of the Tigris (London: Taderon Press, 2012), 50.
} 
the refugees and others."29 During the initial stages of the camp's setup, small groups of Assyrians had put up outposts for themselves and their livestock outside the camp, but as tensions rose between the refugees and the local Arab and Kurdish populations they were ordered to return to the camps, "where they were less likely to be molested at night by Arab thieves." ${ }^{30}$ Much of the evidence points to considerable resentment on the part of local Arab and Kurdish populations over the British, Assyrian, and Armenian appropriation of property and aggressive defense of the camp.

The idea of repatriation and resettlement thus dominated the physical setup of the Ba'quba camp as well as its daily administration and the relationship of Armenian and Assyrian refugees with the surrounding areas. Through 1919, officials like Dudley Northcote declared that the repatriation of the refugees had been delayed only because of the difficulties of crossing hostile Kurdishheld territory on the way to Hakkari, Urmia, or Erevan. As the terms of the peace accord became clearer in 1920, the situation of the refugees became muddier; many of the British administrators running the camp were unwilling to drop the idea of repatriation, even as its impossibility became abundantly evident. F. Cunliffe-Owen, Director of Repatriation in the Ba'quba camp, told the British government as much in 1920:

My conclusions are therefore:-Either (i) Continue the present mode of living with hopes of and efforts for repatriation. In this case the community cannot be self-supporting ... Or (ii) Accept the idea that repatriation is not within the range or practical politics as yet and settle the community in zones which must be found and where the people would have to resume their customary avocations. This could of course entail an initial outlay and would be largely experimental in strange surroundings. I myself recommend the first course. ${ }^{31}$

Such conversations were also governed by increasing concern in London about the costs of the camps and the French mandate government's refusal to provide financial assistance.

When in August of 1920 the British authorities finally made the decision to close Ba'quba, citing the danger posed by the Arab uprisings around Iraq, the fate of the refugees depended on their ethnicity. Initially, they were moved en

\footnotetext{
29 Austin, The Ba'qubah Refugee Camp, 57.

$30 \quad$ Ibid., 58 .

31 Cunliffe-Owen, Memorandum regarding administration of Refugee Camp at Bacqubah, 1920 , т $1 / 12603$.
} 
masse north to Nahr Umar, where they were again divided into Armenian and Assyrian quarters with separate administrations. As many Armenians hopefully awaited the creation of an independent Armenian state as proposed in the Treaty of Sèvres, the British government and the League of Nations simultaneously proposed other resettlement alternatives for the Armenians. One proposal had Armenian refugees placed on an agricultural colony in Kirkuk; others suggested similar rural settlement plans in Syria. Neither of these plans proved acceptable to the refugees themselves, who categorically refused to cooperate, and the British decided simply to evacuate all the camp's inhabitants with a small sum of money to find other accommodation. When this policy was implemented in the fall of 1921, most of Ba'quba's Armenian residents were transported to Transcaucasia, as the closest possible option to repatriation in the now-defunct Armenian nation-state, while the Assyrians in Ba'quba camp, on the other hand, were mainly moved to another refugee camp at Mindan, outside Mosul.

The refugee camps and the subsequent settlements had thus created a rural landscape in which Assyrians constituted a markedly separate political and geographical entity, supported by an external power and placed within restrictive circumstances. This alteration of the rural landscape to create a defined, limited, and fragmented space for Assyrian minority communities was supported by the Iraqi government, who paid part of the costs of the agricultural settlement plan through tax relief and, in some cases, financing of agricultural projects, infrastructure, and housing. Despite this funding, the Iraqi government and emerging Iraqi and Arab nationalist movements came to view these communities with suspicion, as foreign elements representing a potential threat to the sovereignty of the state. This overlaying of the category of "minority" on what was essentially an imported refugee community dependent on outside sponsors had long-term and broadly negative consequences for Iraq's other Christian communities, who did not have the same spatial or political distance from the Iraqi state. ${ }^{32}$

32 On the construction of a more unified "Church of the East" encompassing both Chaldean and Assyrian branches in various historical periods, see especially Murre-van den Berg, "Chaldeans and Assyrians." Because of their origins as refugees and the enclosed nature of the camps, this particular Assyrian community had relatively little contact during the immediate postwar period with other eastern Christian groups in Iraq; the fact that their primary political relationships were with the British isolated them in a different way from other religious and ethnic "minorities" in Iraq. 


\section{Pointing the Way to a Broader Refugee Regime}

Although mass migration of displaced peoples had of course characterized wartime prior to the twentieth century, World War I marked the beginning of an international approach to refugees that defined them first and foremost as stateless and thus a responsibility on the international state system. The Assyrian and Armenian refugee camp that arose under British supervision at Ba'quba predated the emergence of a comprehensive refugee regime under the authority of the new League of Nations, and the nature of the relief arrangements in these early camps and settlements served to shape emerging international refugee policy.

The beginnings of an international refugee regime did not come until 1921, some years after private relief organizations as well as various Allied governments had engaged in the creation of refugee camps across the former Arab provinces of the Ottoman empire. Its first formal iteration was the appointment by the League of a "General Commissioner for the Russian Refugees," at the suggestion of a group of humanitarian agencies including the International Red Cross. The slot was filled by the redoubtable Fridtjof Nansen, who was charged with the task of either finding ways to repatriate refugees to Russia or finding employment for them in their new homes. When, the following year, a new Soviet decree stripped the refugees of their citizenship, Nansen turned his attention to the possibilities of formal legal asylum elsewhere. This development followed on the heels of the collapse of the short-lived Republic of Armenia, which created another wave of Armenian refugees fleeing their territory's incorporation into Turkey or the Soviet state and rendering the idea of "repatriation" impossible for Armenian refugees holed up in camps in Syria, Lebanon, Palestine, and Iraq. Nansen's creation of the Nansen Passport system, at its core, represented an attempt to deal with the loss of the repatriation solution for these Russian and Armenian refugees. ${ }^{33}$

At the same time, despite the expansion of eligibility for the Nansen passport to "Any person of Assyrian or Assyro-Chaldean origin" in 1928, ${ }^{34}$ the League and its associated refugee institutions were already beginning to differentiate between cases like the Russian refugees, for whom emigration, asylum, and eventual assimilation into a new home country were considered desirable, and distinct "national minorities" like the Armenians and Assyrians, for whom

33 On the Nansen Passport, see Watenpaugh, "The League of Nations' Rescue of Armenian Genocide Survivors."

34 "Arrangement of 30 June 1928 Concerning the Extension to Other Categories of Refugees of Certain Measures taken in Favour of Russian and Armenian Refugees," LNTs, 89, p. 63. 
some sort of eventual sovereign space was envisioned and who were being held in enclosed, potentially mobile camps specifically for this purpose. Such distinctions were even clearer in the cases of refugees who were not recognized as political entities at all. During the course of an investigation of non-affiliated refugees in need of the League's assistance, private groups pointed out any number of small groups of refugees across Europe:

150 Assyrians and a small number of Montenegrin refugees in France, 19,00o Assyro-Chaldeans in the Caucasus and Greece, 9,00o Ruthenes in Austria and Czechoslovakia, 100,00o refugees in central Europe, including 10,000 former Hungarians in Austria, France, and Romania, 16,000 Jews in Romania, and 150 Turks in Greece who had been 'Friends of the Allies. ${ }^{35}$

The ensuing discussion in the Council included the observation that "the mere fact that certain classes of persons are without the protection of any national Government is not sufficient to make them refugees," ${ }^{36}$ and it was decided that only the Assyrian, Assyro-Chaldeans, and Turks-all of whom claimed identities that had already been constituted as part of a recognized refugee national group - would be eligible for League assistance.

In the context of the Middle East, then, the premise that the communal and national identities of Armenian and Assyrian refugees represented the primary reason for international intervention on their behalf-intervention that other refugees, not recognized as "minority" national entities, did not merit-had been constructed and disseminated to both the refugees themselves and an international funding audience through the institutionalization of postwar refugee camps like Baquba. Further, the camps created a de facto situation of a moveable, compact, ethnically homogenous "homeland," one which the League considered could be moved and recreated as a sovereign or semisovereign political space when the opportunity opened up.

Ironically, this role - to maintain a nationality until such time as its claims could be realized - rendered refugee camps and settlements, originally conceived in the context of the crisis of war, a permanent part of the new geopolitical landscape of the Middle East. Refugee camps emerged as spaces not only for humanitarian intervention but also for a display of national sovereignty. As such, they demonstrated the League's commitment to the nation-state system, even when the League's members could not see their way clear to the creation

35 Skran, Refugees in Interwar Europe, 114-115.

36 Cited in Skran, Refugees in Interwar Europe, 115. 
of an Armenian or Assyrian state that would require intensive western military and financial assistance to remain viable. The maintenance of refugee camps and settlements as quasi-sovereign spaces (possible only because their host nations were under colonial domination) was intended as a public display of the League's ideological orientation towards national sovereignty.

\section{Conclusions}

The refugee camp at Ba'quba was constituted under a British leadership that assumed Armenian and Assyrian national identity as a primary organizing principle, both in terms of governing approaches and physical space. The spatial dimensions of this refugee experience shaped the concept of the ethnic minority in the new Iraqi state, first by creating camps where ethnic nationalisms could be emphasized, reified, and even invented, and then by moving these dependent refugee communities under British protection to relatively enclosed and homogenous spaces that would become permanent features of the new nation. Under this model, minorities were not just identifiable ethnic, linguistic, or religious communities; they were also constituencies whose negotiations with the Iraqi state necessarily involved a third, imperial, power. Assyrians and Armenians were thus constituted as a threat to the concept of Iraqi sovereignty and to Arab national unity. This postwar understanding of what minorities meant to the new states and their national movements now began to extend to other ethnic and religious communities who had not historically had this relationship with outside powers, who were not refugees, and who were Arabized to a much greater degree.

Even more centrally, refugee camps themselves now became a new kind of political space, designed to represent the concept of national identity and demonstrate the international order's commitment to universal national sovereignty. In the absence of any political will to create Armenian or Assyrian states, refugee camps nevertheless could operate as a public demonstration of the League's maintenance and promotion of the principle of sovereignty for various ethno-nationalisms. In imagining the refugee camp as an enclave for specifically national minorities, the British and the League created a new geopolitical institution that would eventually become a primary feature of the twentieth-century Middle Eastern political landscape. 


\section{Bibliography}

\section{Archival Sources}

LNTS = League of Nations Treaty Series, United Nations Treaty Series. Available online: https://treaties.un.org/pages/LONOnline.aspx

National Archives, Kew

Foreign Office (FO)

Treasury $(\mathrm{T})$

NP = Northcote Papers, British Library, London

\section{Works Cited}

Altug, Seda. "Sectarianism in the Syrian Jazira: Community, Land and Violence in the Memories of World War I and the French Mandate (1915-1939)." Ph.D. thesis, Utrecht University, 2011.

Austin, H.H. The Ba'qubah Refugee Camp: An Account of Work on Behalfof the Persecuted Assyrian Christians. London: Faith House, 1920.

Bayat, Fadil. al-Dawla al-'Uthmaniyya fì l-majal al-'Arabī: Dirāsa tārīkhiyya fì l-awḍ' al-idariyya fi daw' al-wathāiq wa-l-masādīr al-'Uthmaniyya hașran. Beirut: Markaz Dirasat al-Wahdah al-'Arabiyya, 2007.

Braude, Benjamin and Bernard Lewis (eds.). Christians and Jews in the Ottoman Empire: The Functioning of a Plural Society. 2 vols. New York: Holmes and Meier, 1982.

Carmichael, Cathie. Genocide Before the Holocaust. New Haven, ст: Yale University Press, 2009.

Chevalier, Michel. Les montangnards chretiens du Hakkariet du Kurdistan septentrional. Paris: Departement de Geographie de l'Universite de Paris-Sorbonne.

Coakley, J.F. The Church of the East and the Church of England: A History of the Archbishop of Canterbury's Assyrian Mission. Oxford: Clarendon Press, 1992.

Courbage, Youssef and Phillipe Fargues. Chrétiens et juifs dans l'Islam arabe et turc. Paris: Fayard, 1992.

de Courtois, Sébastien. Le génocide oublié: chrétiens d'orient, les derniers araméens. Paris: Ellipses, 2002.

Dodge, Toby. Inventing Iraq: The Failure of Nation Building and a History Denied. New York: Columbia University Press, 2003.

Dogan, Mehmet Ali and Heather J. Sharkey (eds.). American Missionaries and the Middle East: Foundational Encounters. Salt Lake City: University of Utah Press, 2011.

Finkel, Caroline. Osman's Dream: The Story of the Ottoman Empire 1300-1923. New York: Perseus, 2005.

Fuccaro, Nelida. The Other Kurds: Yazidis in Colonial Iraq. London: Tauris, 1999.

Gaunt, David. Massacres, Resistance, Protection: Muslim-Christian Relations in Eastern Anatolia During World War I. London: Gorgias Press, 2006. 
Gualtieri, Sarah. Between Arab and White: Race and Ethnicity in the Early Syrian American Diaspora. Berkeley: University of California Press, 2009.

Inalcik, Halil, et al. (eds.) An Economic and Social History of the Ottoman Empire, 13001914. 2 vols. Cambridge: Cambridge University Press, 2004.

Joseph, John. The Modern Assyrians of the Middle East: Encounters with Western Christian Missions, Archeologists, and Colonial Powers. Leiden: Brill, 2000.

Khoury, Philip. Syria and the French Mandate: The Politics of Arab Nationalism, 19201945. Princeton, NJ: Princeton University Press, 1987.

Laycock, Jo. Imagining Armenia: Orientalism, Ambiguity, and Intervention. Manchester: Manchester University Press, 2009.

Makdisi, Ussama. Artillery of Heaven: American Missionaries and the Failed Conversion of the Middle East. Ithaca, NY: Cornell University Press, 2008.

Masters, Bruce. Christians and Jews in the Ottoman Arab World: The Roots of Sectarianism. Cambridge: Cambridge University Press, 2001.

Méouchy, Nadine, and Peter Sluglett (eds.). The British and French Mandates in Comparative Perspective. Leiden: Brill, 2004.

Murre-van den Berg, Heleen. "Chaldeans and Assyrians: The Church of the East in the Ottoman Period," in Erica Hunter (ed.), The Christian Heritage of Iraq, 157-161. Piscataway, NJ: Gorgias Press, 2009.

"Light from the East (1948-1954) and the De-Territorialization of the Assyrian Church in the East," in Wim Hofstee and Arie van der Kooij (eds.), Religion Beyond its Private Role in Modern Society, 115-134. Leiden: Brill, 2013.

(ed.). New Faith in Ancient Lands: Western Missions in the Middle East in the Nineteenth and Early Twentieth Centuries. Leiden: Brill, 2006.

Neep, Daniel. Occupying Syria under the French Mandate: Insurgency, Space, and State Formation. Cambridge: Cambridge University Press, 2012.

Norris, Jacob. Land of Progress: Palestine in the Age of Colonial Development, 1905-1948. Oxford: Oxford University Press, 2013.

Pedersen, Susan. "The Meaning of the Mandates System: An Argument." Geschichte und Gesellschaft 32, no. 4 (2006): 560-582.

de Planhol, Xavier. Minorités en Islam: géographie politique et sociale. Paris: Flammarion, 1997.

Quataert, Donald. The Ottoman Empire, 1700-1922. New York: Cambridge University Press, 2000.

al-Rasheed, Madawi. Iraqi Assyrian Christians in London: The Construction of Ethnicity. Lewiston, NY: Edwin Mellen Press, 1998.

Robson, Laura. Colonialism and Christianity in Mandate Palestine. Austin: University of Texas Press, 2011.

Shahoian, Levon. On the Banks of the Tigris. London: Taderon Press, 2012.

Silverfarb, Daniel. Britain's Informal Empire in the Middle East: A Case Studyof Iraq, 19291941. New York: Oxford University Press, 1986. 
Simon, Reeva and Eleanor Tejirian (eds.). The Creation of Iraq, 1914-1921. New York: Columbia University Press, 2004.

Sluglett, Peter. "An Improvement on Colonialism? The 'A' Mandates and Their Legacy in the Middle East." International Affairs 90, no. 2 (2014): 413-427.

Tejirian, Eleanor H. and Reeva Spector Simon. Conflict, Conquest, and Conversion: Two Thousand Years of Christian Missions in the Middle East. New York: Columbia University Press, 2012.

Thompson, Elizabeth. Colonial Citizens: Republican Rights, Paternal Privilege, and Gender in French Syria and Lebanon. New York: Columbia University Press, 1999.

Travis, Hannibal. "The Assyrian Genocide: A Tale of Oblivion and Denial," in Rene Lemarchand (ed.), Forgotten Genocides: Oblivion, Denial, and Memory, 123-136. Philadelphia: University of Pennsylvania Press, 2011.

- Genocide in the Middle East: The Ottoman Empire, Iraq, and Sudan. Durham, NC: Carolina Academic Press, 2010.

Tripp, Charles. A History of Iraq. 2nd ed. Cambridge: Cambridge University Press, 2000.

Watenpaugh, Keith. "The League of Nations' Rescue of Armenian Genocide Survivors and the Making of Modern Humanitarianism, 1920-1927." American Historical Review 115, no. 5 (2010): 1315-1339.

Wigram, W. The Assyrians and their Neighbors. London: Bell Press, 1929.

Zubaida, Sami. "Contested Nations: Iraq and the Assyrians." Nations and Nationalism 6 , no. 3 (200o): $363-382$. 